Original Article

\title{
Homeopathy emerging as nanomedicine
}

\author{
Rajendra Prakash Upadhyay¹, Chaturbhuja Nayak ${ }^{2}$
}

\author{
(1) Department of Bio-chemical Engineering and Biotechnology, Indian Institute of \\ Technology (IIT) Delhi, New Delhi, India \\ (2) Central Council for Research in Homeopathy, New Delhi, India
}

\begin{abstract}
Background: Homeopathy is a time-tested two-century old empirical system of healing. Homeopathic medicines are prepared through a characteristic process known as potentization, where serial dilutions are performed with strong strokes at each step of dilution. Homeopathy is controversial because most medicines do not contain one single molecule of the corresponding starting-substance. Aim: To investigate a possible nanoscience mechanism of action of homeopathic medicines. Methodology: Ultra-pure samples were prepared and were examined under scanning (SEM) and transmission electron microscope (TEM) along with selected area nanodiffraction (SAD) and energy-dispersive X-ray analysis (EDX). Also trace element analysis (TEA) for silicon was performed. Results: Homeopathic medicines showed not to be 'nothing', but exhibited nanoparticles and conglomerates of them, which had crystalline nature and were rich in silicon. Conclusions: During the violent strokes involved in potentization, information arising from the serially diluted starting-substance might be encrypted by epitaxy on silicon-rich crystalline nanoparticles present in the resulting homeopathic medicine. The 'size' of the information encrypted on nanoparticles might vary together with the degree of dilution. As homeopathic medicines exhibit healing effects, these nanoparticles along with the interfacial water on their surface might carry this information - which biological systems are able to identify - to the target. As various forms of silica are known to interact with proteins and cells of the immune system, homeopathy might represent a nanomedicine system. Possible confirmation, however, requires further research in materials and interfacial water.
\end{abstract}

Keywords: homeopathy; epitaxy; nanoparticle; interfacial water; nanomedicine.

\section{Introduction}

\section{Background}

Homeopathic medicines are prepared through a characteristic process known as potentization. Potentization involves serial dilution and agitation (by means of strong strokes) or trituration at each stage. Trituration consists in the fine grinding of a starting-substance with lactose, which is used when the starting-substance is not soluble in water or alcohol. Potency levels are designated as ' $x$ ' (or ' $d$ ') and 'c' when they are diluted 1:9 and 1:99 respectively at each stage. Without agitation (or trituration), a dilution is thought to be devoid of any therapeutic effect and should not be termed potency. For example, potency 12cH was diluted 1:99 12 times with strong strokes at each dilution level; 'H' here stands for Hahnemann's method. According to Avogadro's number, there should be no molecule of the starting-substance in potencies above $12 \mathrm{cH}$. Nevertheless, much higher centesimal potencies, such as $200,1,000,10,000 \mathrm{cH}$, etc. are routinely used in homeopathic clinical practice with satisfactory results. 
From the perspective of conventional medicine, all homeopathic medicines are nothing but placebo used to give some psychological relief to patients. Despite all criticism, the time-tested clinical results of homeopathy observed also in infants caused widespread popularity among users.

Reilly et al. [1] concluded that since homeopathy elicits much more than placebo responses it is an empirical puzzle and a challenge to orthodox scientific models. A strategy for structural exploration of homeopathic medicines was suggested [2]. With the advent of new tools supplied by nanoscience and nanotechnology, new research paths were opened. The aim of this study was to investigate possible nanoparticles/materials in homeopathic medicines, and if positive, to examine whether this suffices to qualify homeopathy as a form of nanomedicine.

\section{Current Status of Research}

The composition and properties of bulk water was the subject of much study, however very little attention was paid to the suspended solid phases that make it ultra-diluted aqua sols [3]. As succussion is mandatory in the preparation of homeopathic potencies, epitaxy was adduced to explain the transfer of structural information even in the absence of starting-substance [4].

Epitaxy is a frequently observed phenomenon in materials science and technology, especially in the fabrication of semiconductors. It refers to the transfer of structural information without transferring matter, whereupon crystalline material grows on the surface of another mimicking the structure of the latter. Therefore, the so-called silica hypothesis might be considered an important framework for the understanding of the mechanism of action of homeopathic medicines [5].

A recent study [6] with market samples of some metal-derived homeopathic medicines found that extreme homeopathic dilutions retain the starting materials in the form of nanoparticles. The size distribution of these nanoparticles and their clusters was found to be nearly the same in different potencies. Nevertheless, the opposite was observed in a different study [7] on membrane anisotropy, suggesting that the cluster's size decreases with the increasing potency. Further, a seeming hurdle in the explanation of extreme homeopathic dilutions, Avogadro's constant was doubted for its validity [8].

There are some interesting observations regarding the preparation of homeopathic medicines, which might provide clues for their understanding. Homeopathic potencies (medicines) have always been prepared in glass vials. Witt et al. [9] suggested that when these vials are lined up with paraffin, their effects decrease and further, upon addition of powdered glass to potencies prepared in plastic vials, the lost effects reappear.

Moreover, recent developments in the understanding of interfacial water are truly extraordinary [10]. This water has not been as much studied and understood as bulk water. It is coherent and liquid crystalline in nature, and it exhibits strange properties. Also the properties of nanoparticles are rated 'strange' compared to their bulk matter. Both are new fields of studies and much has yet to come out.

Quite recently Montagnier et al [11] reported the presence of electromagnetic signals produced by DNA sequences in high aqueous dilutions. This opened up a new area of research also in homeopathy, since homeopathic medicines may be tested for electromagnetic signals emission and if affirmative, studies may be designed to establish how the information carried by a starting-substance is transferred to high-dilutions during the process of potentization. 


\section{Material and Methods}

\section{Sample Preparation}

We prepared samples of plant-derived homeopathic medicines Colchicum, Pulsatilla and Belladonna obtained as mother-tincture from Schwabe India; we decided to prepare the medicines by ourselves to grant ultrapurity and to develop controls to compare results. Potencies were prepared up to $15 \mathrm{cH}$, where the startingmaterial is unlikely to be any longer present. Simple dilutions without agitation (strokes) were also prepared from the respective mother-tinctures up to the $15^{\text {th }}$ centesimal level to serve as controls. Potencies of ultrapure Milli-Q water were also potentiated up to $15 \mathrm{cH}$ as another control. All these dilutions were prepared in borosilicate glass vials (Schott Duran, Germany). Potencies were also prepared up to $15 \mathrm{cH}$ in plastic vials (Tarsons, material: PP autoclavable) containing no glass whatsoever to observe the alleged interference of glass in the preparation of samples.

All samples were prepared in clean containers using Milli-Q water (electrical conductivity $18.2 \mathrm{M} \Omega \times \mathrm{cm}$ ) and alcohol (99.5\%, pharmacopoeia grade, Merck, Germany) as per established methodologies. Samples were prepared in $89 \%$ alcohol (v/v) by the same person to avoid variations in strokes. Dilution was performed according to the standard centesimal ratio 1:99 for starting-material and diluent medium respectively by means of micropipette with disposable plastic tips in sterile conditions under laminar hood (clean environment). As no trituration was performed at any stage, lactose crystals were not present in samples.

\section{Scanning Electron Microscopic (SEM) Studies of Samples}

SEM was performed on samples with Zeiss EVO 50 equipment. To prepare specimens, one drop of sample was air-dried on a glass cover slip and mounted on a holder. Since these are nonconductive solid specimens, they were coated with an ultrathin layer of electrically conducting material gold laid on the sample by sputter coating (EMITECH K550X). Such coating prevented the accumulation of static electric charge on the specimen during electron irradiation and also increased the signal, thus improving contrast and resolution.

\section{Transmission Electron Microscopic (TEM) Studies of Samples}

TEM was performed on samples by means of Technai G20-stwin (200kV) with EDAX attachment (EDAX Company USA). The carbon-coated grid was dipped in the sample and let to dry before observation. Selected area nanodiffraction (SAD) patterns with TEM were also obtained. Also energy-dispersive X-ray (EDX or EDAX) analysis was performed.

\section{Trace element analyses for silicon}

TEA for silicon was performed in the $15 \mathrm{cH}$ samples by means of inductively coupled plasma - optical emission spectroscopy (ICP-OES) with VARIAN Make - model Vista MPX.

\section{Results}

\section{Study of samples by SEM}

Samples (homeopathic medicines and controls) showed presence of material even above dilution level $12 \mathrm{cH}$, where the starting-substance is unlikely to be present according to Avogadro's number (Figures 1-4). However, very low potencies such Pulsatilla $1 \mathrm{cH}$ and Pulsatilla $2 \mathrm{cH}$ most likely still exhibit startingsubstance material (Figure 5). 


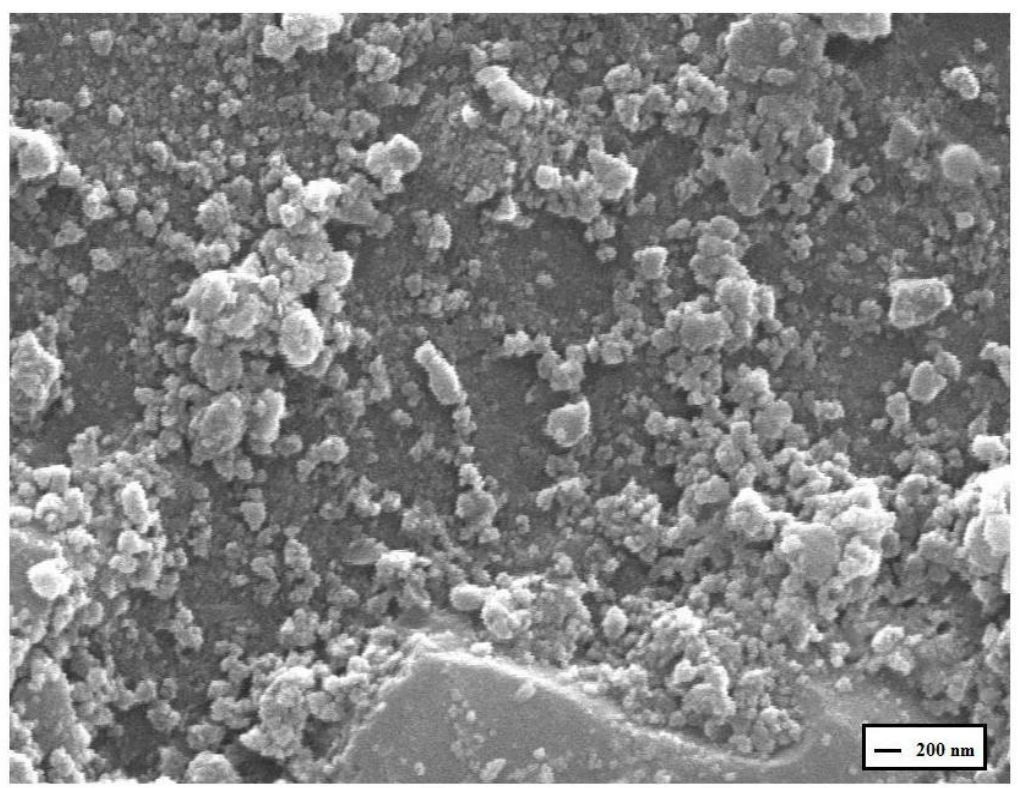

Figure 1 - Scanning electron microscope (SEM) image of Colchicum $15 \mathrm{cH}$ (homeopathic medicine) showing nanomaterials.

Figure 2 - Scanning electron microscope (SEM) image of Colchicum $15 \mathrm{cH}$ (homeopathic medicine) showing conglomerate.
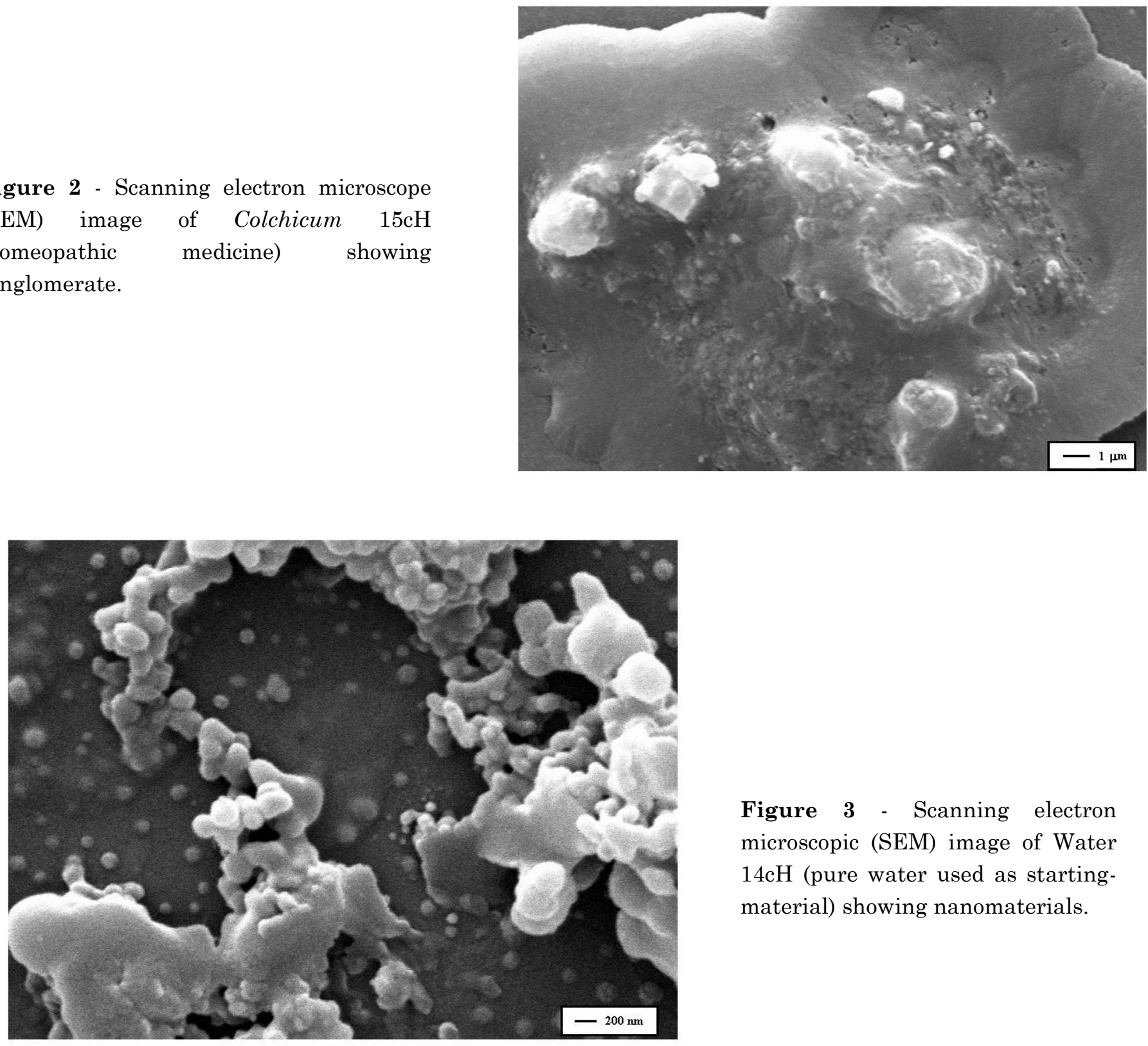

Figure 3 - Scanning electron microscopic (SEM) image of Water $14 \mathrm{cH}$ (pure water used as startingmaterial) showing nanomaterials. 


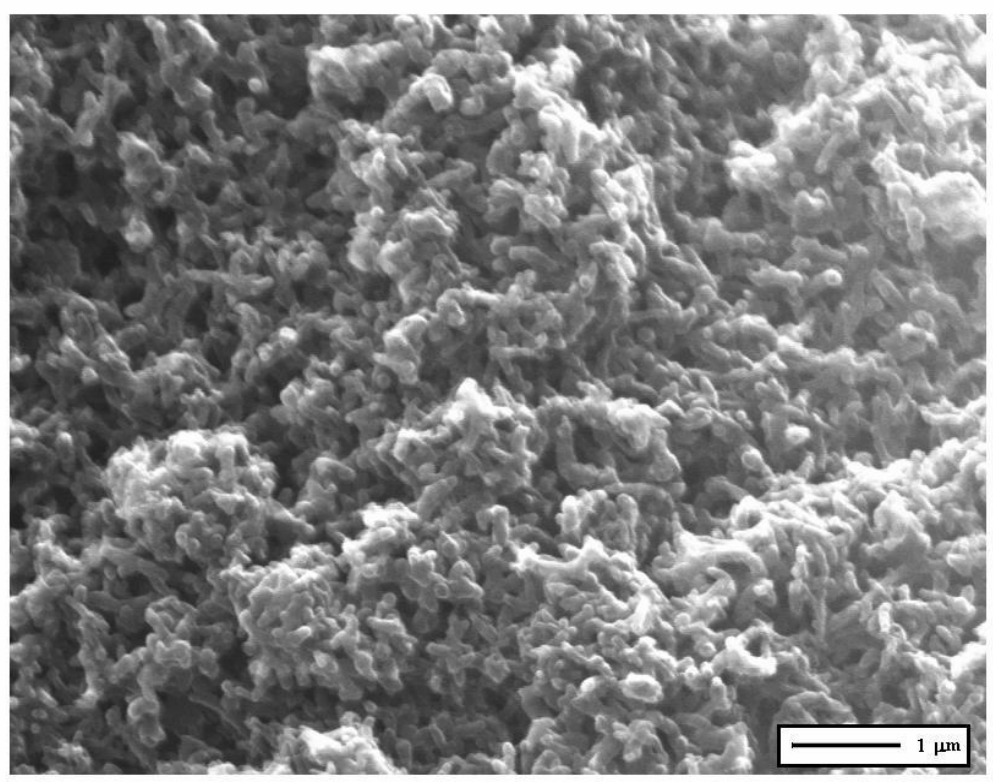

Figure 4 - Scanning electron microscope (SEM) image of Colchicum 15cH: a control prepared in plastic vials showing nanomaterial, however, its appearance differs from samples prepared in glass vials.
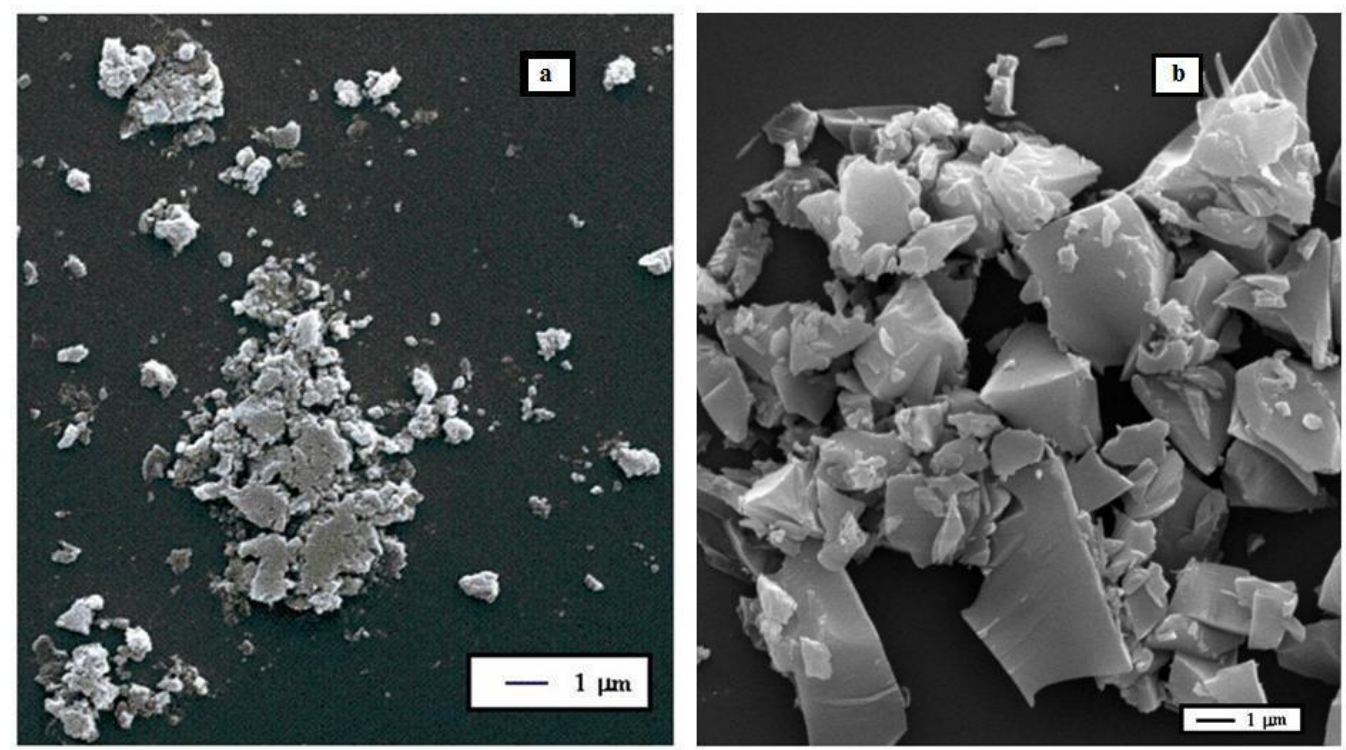

Figure 5 - Scanning electron microscope (SEM) images of homeopathic medicines (a) Pulsatilla 1cH and (b) Pulsatilla $2 \mathrm{cH}$, where the starting-substance is most likely present. Materials seen are lumps of nanoparticles as they formed in the area imaged. One drop of sample was dried on a glass cover slip under clean laminar airflow and nanomaterial was looked for in that drop in a nanoscale vast area. Wherever such materials with some interesting form were found, the corresponding extremely small area was imaged. 


\section{Study of samples by TEM}

Nanoparticles/materials were observed in homeopathic medicines (Figures 6-7) as well as in controls (Figure 8). However, during experiments nanoparticles/material were comparatively more easily found in homeopathic medicines because they exhibited better presence. Leaching also occurred in simple dilutions without agitation but in lower amounts. Figure 8 might be a nanochunk peeled off the glass vial with nanoparticles.

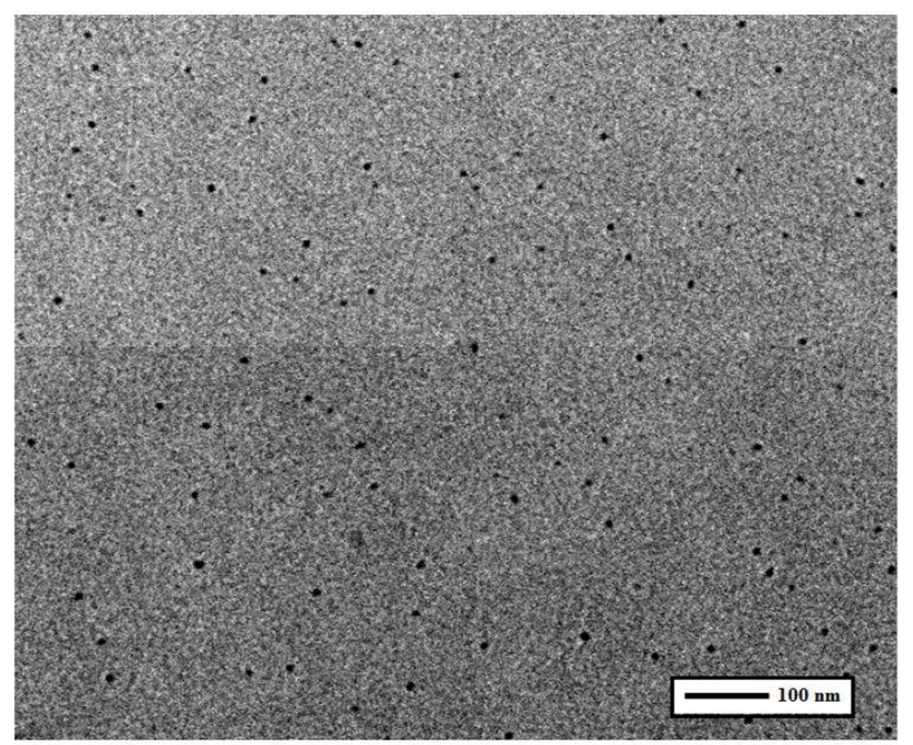

Figure 6 - Transmission electron microscope (TEM) image of homeopathic medicine Pulsatilla $15 \mathrm{cH}$ showing nanoparticles.

Figure 7 - Transmission electron microscope (TEM) image of homeopathic medicine Pulsatilla $15 \mathrm{cH}$ showing nanoparticles with conglomerate.

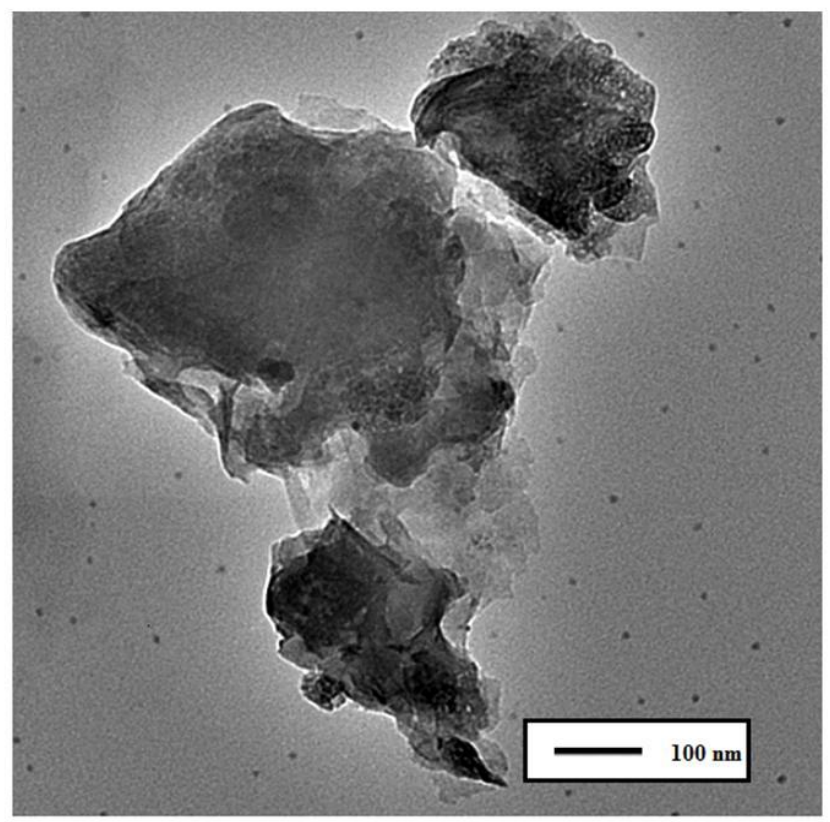




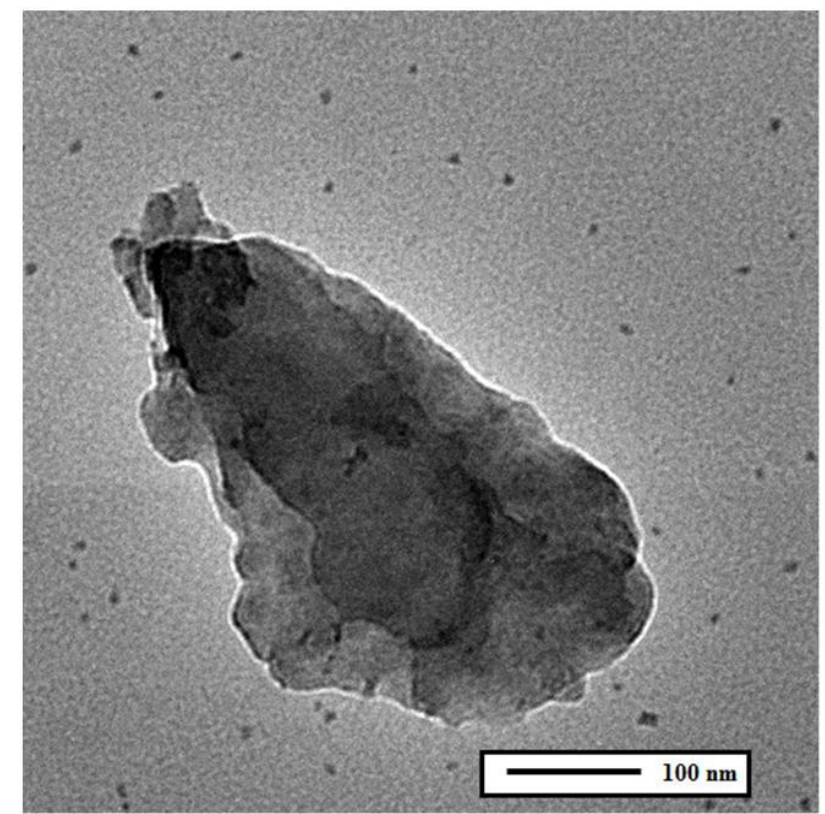

Figure 8 - Transmission electron microscope (TEM) image of Pulsatilla $15^{\text {th }}$ centesimal dilution (without agitation) showing nanoparticles with conglomerate or a nanochunk.

SAD by TEM instrument indicated the crystalline nature of the nanomaterial present in homeopathic medicines (potencies). Similarly, also nanomaterials present in controls (dilutions without succussion and plastic vessel potencies) had crystalline nature. (Figure 9)
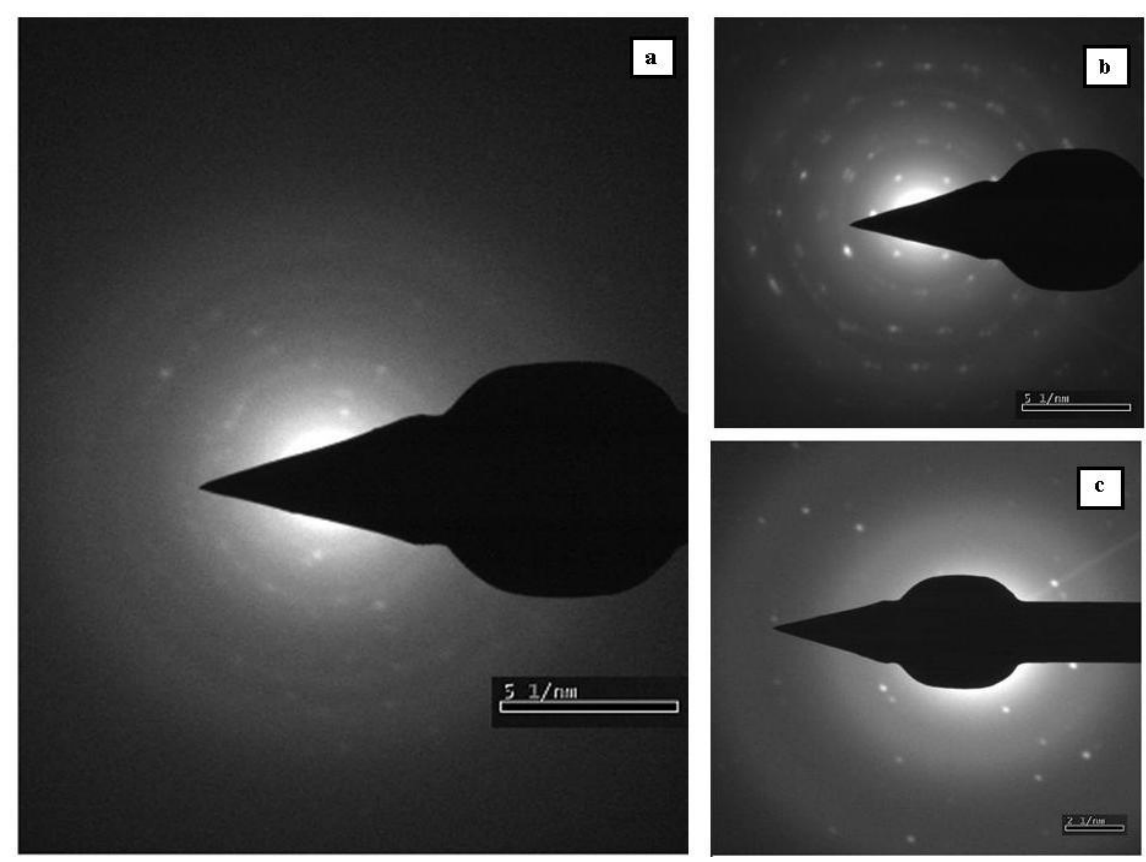

Figure 9 - Selected area nanodiffraction (SAD) patterns for (a) Pulsatilla 15cH (homeopathic medicine), (b) Pulsatilla 15th centesimal dilution without agitation (control), and (c) Pulsatilla 15cH prepared in plastic vials (control): all show the crystalline nature of the present material. 
EDX showed high silicon contents in the nanoparticles present in homeopathic medicines (potencies) prepared in glass (Figure 10). Such high silicon content was not observed in nanoparticles present in controls.
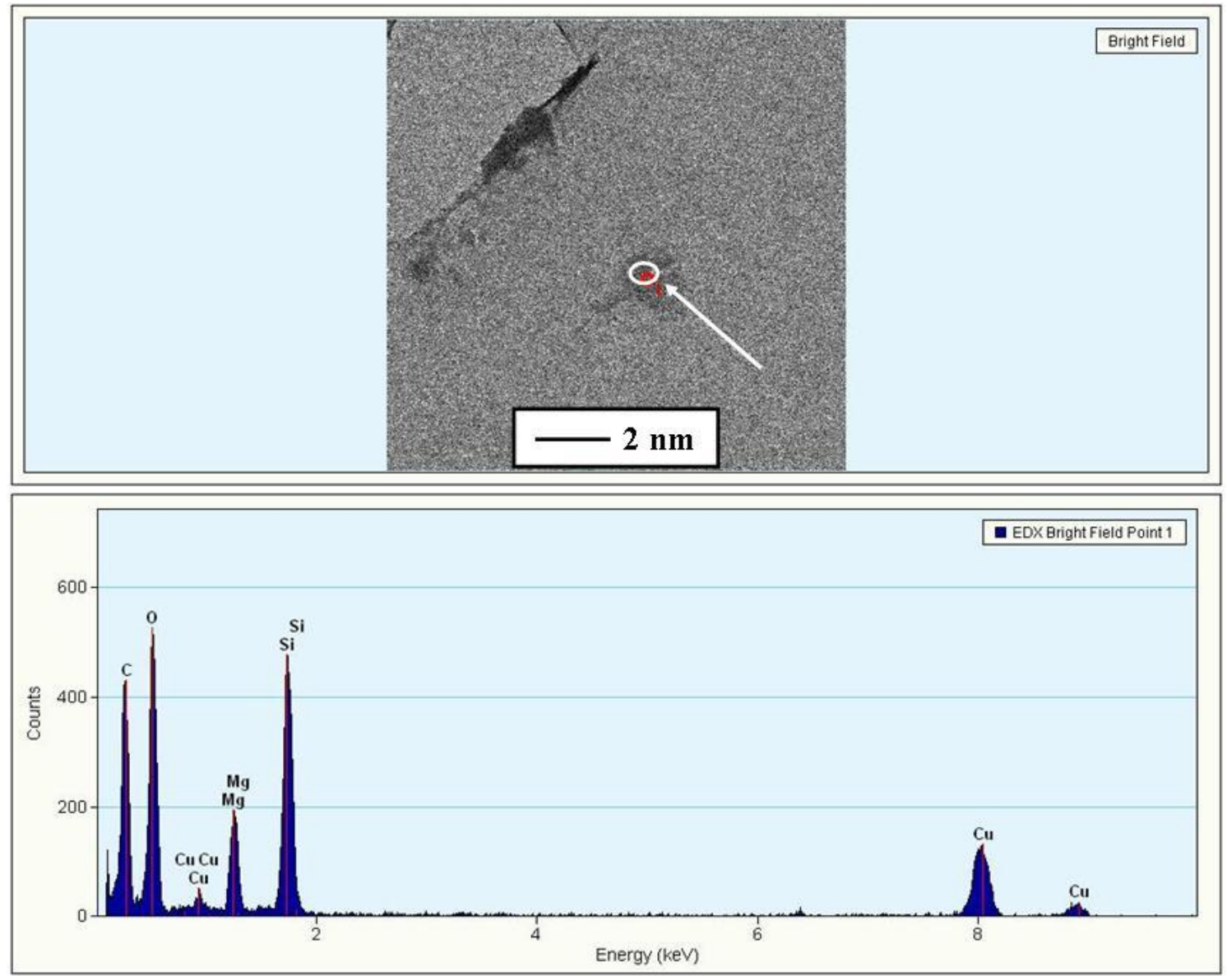

Figure 10 - Energy-dispersive X- ray (EDX) analysis of the selected area using carbon coated copper grid for homeopathic medicine Colchicum $15 \mathrm{cH}$ showing high silicon content.

\section{Trace element analysis (TEA) for silicon}

Samples prepared in glass vials where agitation (strong strokes) was performed (namely, homeopathic medicines and potency of water) had high and nearly the same silicon content. Dilutions without agitation, which are not homeopathic medicines, had one-third silicon content compared to samples prepared in glass vials where agitation was performed. Dilutions with agitation (i.e. potencies) in plastic exhibited the lowest silicon content. Therefore, TEA for silicon confirms the high presence of silicon in homeopathic medicines (potencies) compared to controls. It is obvious that silicon leaches from the glass wall of vials, especially during the strokes of potentization irrespective of the starting-substance. (See Table 1) 
Table 1 - Trace element analysis (TEA) of samples for silicon by inductively coupled plasma- optical emission spectroscopy (ICP-OES)

\begin{tabular}{|l|l|c|c|}
\hline S.No. & Name of sample & Samples detail & Silicon content (ppm) \\
\hline \multirow{4}{*}{1} & Pulsatilla $15 \mathrm{cH}$ & Potencies, i.e. medicines & 2.4 \\
& Colchicum $15 \mathrm{cH}$ & & 2.3 \\
& Belladonna $15 \mathrm{cH}$ & Dilutions without agitation, & 2.4 \\
\hline \multirow{3}{*}{2} & Pulsatilla $15^{\text {th }}$ cent. dil. & i.e. controls & 0.8 \\
& Colchicum $15^{\text {th }}$ cent. dil. & Potency of water, i.e. control & 0.7 \\
\hline 3 & Belladonna $15^{\text {th }}$ cent. dil. & & 2.3 \\
\hline \multirow{3}{*}{4} & Water $15 \mathrm{cH}$ & Potencies prepared in plastic & 0.4 \\
& Colsatilla $15 \mathrm{cH}$ & vials, i.e. controls & 0.3 \\
& Belladonna $15 \mathrm{cH}$ & & 0.3 \\
\hline
\end{tabular}

\section{Discussion: Do homeopathic medicines qualify as nanomedicines?}

The dose of homeopathic medicine a patient takes may contain few (or zero) molecules/atoms of the startingsubstance, but this fact alone does not make homeopathic medicines a variety of nanomedicines [12]. Toumey [12] compared homeopathic to nanomedicines, and quoting the example of nanomedicine Aurimune ${ }^{\circledR}$, argued that nanomedicines differ from homeopathic medicines. The major difference is the use of a known amount of medicine in case of nanomedicines compared to homeopathic medicines. In addition, gold nanoparticles in nanomedicine Aurimune ${ }^{\circledR}$ act as the carriers of the active agent to the target.

In the case of homeopathic medicines, crystalline silica (or silicon) nanoparticles (along with other trace elements leaching from the glass wall of the vial) with interfacial water on their surface may acquire the structural information of the starting-substance during the process of potentization. In medium and high potencies, which are commonly used in clinical practice, the presence of starting-source is likely to be zero but it is 'immaterial'. It may be argued that what matters here is the 'size' of the possible encrypted information, perhaps with the electromagnetic signature of the starting-substance. Such 'size' might derive from the dilution level of the homeopathic medicine, since homeopathic medicines in different potencies exhibit different effects and properties. Furthermore, silica (or silicon) nanoparticles might also act as carriers of information. Such nanocarriers might convey the information of the starting-substance - which biological systems are able to identify - to the target, which the starting-substance molecules in themselves are not able to reach. The target, however, is unlikely to be local because homeopathy is rated a holistic therapy assumed to work by means of the immune system. It is worth to remark that various forms of silica are known to interact with proteins and cells of the immune system [13].

As homeopathic medicines might have both the 'size' of the information of the diluted away starting-substance and the carriers needed to convey this information - which biological systems are able to identify - to the target, they may qualify as nanomedicines. Consequently, the nature, composition and surface features of the crystalline material (along with interfacial water) present in homeopathic medicines compared to controls have paramount importance. These must be further investigated, while keeping an eye also on possible electromagnetic emission. This investigation requires suitable developments in the fields of materials and interfacial water. 


\section{Conclusions}

Three homeopathic medicines very frequently used in clinical practice were found not to be 'nothing', but exhibited high nanoparticle contents. Such nanoparticles were rich in silicon and had crystalline nature. During the strong strokes of potentization, the nanoparticles might acquire the information of the diluted away starting-source encrypted on them by means of epitaxy. As various forms of silica are known to interact with proteins and cells of the immune system, these nanoparticles (along with the interfacial water on their surface) might also act as carriers of this information to the target. The 'size' of information might be related with the dilution degree of medicines. Under such possible conditions, homeopathy qualifies as a nanomedicine system not requiring high technology. For confirmation and further elaboration purposes, new research in materials and interfacial water are required.

\section{Acknowledgements}

This work was carried out under the supervision of Prof. Prashant Mishra, Department of Biochemical Engineering \& Biotechnology, Indian Institute of Technology Delhi, New Delhi. Thanks are also given to Dr. Ch. Raveendar and Dr. K. R. Janardanan Nair of Central Council for Research in Homeopathy, New Delhi for administrative help. Part of this work was financially supported by the Central Council for Research in Homeopathy, New Delhi, India under the collaborative program.

\section{References}

[1] Reilly DT, Taylor MA, Mc Sharry C, Aitchinson T. Is homeopathy a placebo response? Controlled trial of homeopathic potency with pollen in hayfever as a model. Lancet.1986; 18: 881-886.

[2] Upadhyay RP. A strategy for structural exploration of homeopathic medicine. Frontier Perspectives. 2003; 12(2): 7-8.

[3] Rao ML, Roy R, Bell I. Characterization of the structure of ultra dilute sols with remarkable biological properties. Mater Lett. 2008; 62: 1487-1490.

[4] Roy R, Tiller WA, Bell I, Hoover MR. The structure of liquid water; novel insights from materials research; potential relevance to homeopathy. Mater Res Innovations. 2005; 9(4): 577-608.

[5] Anick DJ, Ives JA. The silica hypothesis for homeopathy: physical chemistry. Homeopathy. 2007; 96: 189195.

[6] Chikramane PS, Suresh AK, Bellare JR, Kane SG. Extreme homeopathic dilutions retain starting materials: A nanoparticulate perspective. Homeopathy. 2010; 99: 231-242.

[7] Nandy P, Bhandary S, Das S, Basu R, Bhattacharya S. Nanoparticles and membrane anisotropy. Homeopathy. 2011; 100: 194-197.

[8] Chirumbolo S. Molecules and nanoparticles in extreme homeopathic dilutions: is Avogadro's Constant a dogma? Homeopathy. 2011; 100: 107-108. 
[9] Witt CM, Ludtke R, Weisshuhn TE, Quint P, Willich SN. The role of trace elements in homeopathic preparations and the influence of container material, storage duration, and potentization. Forsch Komplementarmed. 2006; 13(1): 15- 21.

[10] Zheng J-M, Chin W-C, Khijniak E, Khijniak E Jr, Pollack GH. Surfaces and Interfacial Water: Evidence that hydrophilic surfaces have long-range impact. Adv Colloid Interface Sci. 2006; 127: 19-27.

[11] Montagnier L, Aissa J, Ferris S, Montagnier JL, Lavallee C. Electromagnetic signals are produced by aqueous nanostructures derived from bacterial DNA sequences. Interdiscip Sci Comput Life Sci. 2009; 1: 8190.

[12] Toumey C. Small differences. Nat Nanotechnol. 2009; 4: 275.

[13] Xynos ID, Edgar AJ, Buttery LDK, Hench LL, Polak JM. Ionic products of bioactive glass dissolution increase proliferation of human osteoblasts and induce insulin-like growth factor II mRNA expression and protein synthesis. Biochem Biophys Res Commun. 2000; 276: 461-465.

\title{
A homeopatia emerge como forma de nanomedicina
}

\begin{abstract}
RESUMO
Introdução: A homeopatia é um sistema de medicina empírica comprovada pelo teste do tempo faz dois séculos. Seus medicamentos são preparados através um processo típico conhecido como potenciação, no qual são realizadas diluições seriadas acompanhadas de intensa agitação em cada passo do processo. A homeopatia é objeto de controvérsia, porque a imensa maioria dos medicamentos utilizados não contém nenhuma molécula da substância de origem. Objetivo: Examinar medicamentos homeopáticos visando o seu possível mecanismo de ação à luz da nanociência. Metodologia: Foram preparadas amostras ultra puras, que foram examinadas sob microscopia eletrônica de varredura (MEV) e de transmissão (TEM) junto de nano-difração de área selecionada (SAD) e energia dispersiva de raios X (EDX). Também foi realizada análise de elementostraço para silício. Resultados: Os medicamentos homeopáticos não resultaram ser "nada", mas continham bastantes nanopartículas e os conglomerados destas mostraram estrutura cristalina, rica em silício. Conclusões: Durante a agitação intensa que faz parte do processo de potenciação, a informação relacionada com a substância gradualmente diluída poderia ser codificada através de epitaxe por nanopartículas cristalinas ricas em silício presentes no medicamento resultante. O 'tamanho' da informação assim codificada poderia acompanhar o grau das potências. Sendo que os medicamentos homeopáticos possuem efeitos curativos, sua informação - que os sistemas biológicos são capazes de interpretar - poderia ser transportada por essas nanopartículas junto da água interfacial na superfície delas até o alvo. Sabe-se que tais nanopartículas, como outras várias formas do silício, são capazes de interagir com proteínas e com células do sistema imune, de maneira que a homeopatia poderia constituir uma forma de nanomedicina. A possível confirmação, no entanto, exige novos caminhos de pesquisa em materiais e água interfacial.
\end{abstract}

Palavras-chave: homeopatia; epitaxia; nanopartículas; água interfacial; nanomedicina. 


\section{La homeopatía aparece como forma de nanomedicina}

\section{RESUMEN}

Introducción: La homeopatía es un sistema empírico de medicina comprobado por la prueba del tiempo hace dos siglos. Sus medicamentos son preparados mediante un procedimiento típico llamado potenciación, durante el cual son realizadas diluciones seriadas acompañadas por intensa agitación en cada paso de preparación. La homeopatía es controvertida porque la mayoría de los medicamentos utilizados carecen de una única molécula de la sustancia de origen. Objetivo: Estudiar el posible mecanismo de acción de los medicamentos homeopáticos a la luz de la nanociencia. Metodología: Se preparó muestras ultra puras que fueron examinadas bajo microscopía electrónica de barrido (SEM) y de trasmisión (TEM) junto con nano-dispersión de área seleccionada (SAD) y energía dispersiva de rayos X (EDX). También fue realizado análisis de trazos de elementos para sílice. Resultados: Los medicamentos homeopáticos no resultaron ser "nada", sino que contenían bastantes nanopartículas y los conglomerados de estas prestaron naturaliza cristalina rica en sílice. Conclusiones: Durante la fase de agitación intensa del proceso de potenciación, la información correspondiente a la sustancia en gradual disolución puede ser codificada por nanopartículas cristalinas ricas en sílice presentes en el medicamento homeopático resultante mediante epitaxis. El 'tamaño' de la información codificada puede ser paralelo al grado de la potencia medicamentosa. Como los medicamentos homeopáticos presentan efectos curativos, esas nanopartículas y el agua interfacial en su superficie podrían ser los portadores de esta información (que los sistemas biológicos son capaces de identificar) hasta el blanco. Se sabe que esas nanopartículas, como otras formas de sílice, son capaces de interactuar con proteínas y céluals del sistema inmune, de modo que la homeopatía podría representar una forma de nanomedicina. Sin embargo, posible confirmación exige nuevas vías de pesquisa en materiales agua interfacial.

Palabras-clave: homeopatia; epitaxia; nanopartículas; agua interfacial ; nanomedicina.

\section{(c)) BY-NC-ND Licensed to GIRI}

Support: Part of this work was financially supported by Central Council for Research in Homeopathy, New Delhi, India. Conflict of interest: authors declare there is no conflict of interest

Received: 05 October 2011; Revised: 18 November 2011; Published: 20 December 2011.

Correspondence author: Rajendra Prakash Upadhyay. Ph.D (Physics), D.I.Hom. (UK), Department of Bio- Chemical Engineering \& Biotechnology, Indian Institute of Technology (IIT) Delhi, New Delhi, India, www.iitd.ac.in , upadhyayrp@rediffmail.com

How to cite this article: Upadhyay RP, Nayak C. Homeopathy emerging as nanomedicine. Int J High Dilution Res [online]. 2011 [cited YYYY Month dd] $\quad 10(37)$ : 299-310. Available from:

http://www.feg.unesp.br/ ojs/index.php/ijhdr/article/view/525/551 